\title{
NOG EEN OPMERKING OVER „REKENINGLOZE” DEBITEUREN-ADMINISTRATIE
}

\author{
door J. Boom
}

Het artikel van Drs Sj. Muller over de ,rekeningloze" debiteurenadministratie (27e jaargang Januari 1953 no. 1), waarvan ik met belangstelling en waardering kennis nam, geeft mij aanleiding tot het maken van een aanvullende opmerking, die wellicht van belang kan zijn voor Uw lezers.

De Heer Muller noemt een tweetal bezwaren tegen een chronologische opberging - die bij de rekeningloze administratie noodzakelijk is - t.w.:

1e. bij ontvangst van betalingen kan de daarbij behorende factuurcopie niet zonder meer worden opgezocht;

2e. het uitoefenen van credietcontrôle (met raadpleging van de openstaande posten) is bij chronologische opberging nagenoeg onmogelijk.

Deze bezwaren kunnen z.i. worden opgelost door naast de chronologisch opgeborgen copiefacturen een kaartsysteem aan te houden, waarvan de kaarten op andere wijze (b.v. per naam of per reizigersdistrict op naam) zijn gegroepeerd.

Ik ben echter van mening dat men de arbeid, verbonden aan het bijhouden van dit kaartsysteem geheel kan besparen indien men van de uitgaande facturen twee afschriften maakt in verschillende kleuren.

Het eerste afschrift (wit) wordt dan chronologisch opgeborgen en het andere (rood) b.v. op naam of per reizigersdistrict op naam.

De rode copie dient dan voor het vaststellen van de factuurdatum bij ingekomen betalingen en voor het uitoefenen van de crediet-contrôle. Beide copieën worden afgestempeld met een ..betaald"-stempel dat gecombineerd is met een datumstempel of numeroteur.

De witte copie wordt na betaling uit de verzameling verwijderd. De rode copieën kunnen na een jaar of langer, afhankelijk van de omvang (hanteerbaarheid) van de map of mappen, worden afgelegd.

De bovenomschreven werkwijze geeft iets meer sorteerwerk (de rode copieën). Het schrijfwerk blijft echter geheel achterwege en de kans op fouten maken is zeer gering. 